\title{
A CASE OF MIXED CONNECTIVE TISSUE DISORDER WITH INTERSTITIAL LUNG DISEASE: CASE REPORT
}

\author{
Bency K. Thomas ${ }^{1}$, Praveen Radhakrishnan'2, S. Yuvarajan ${ }^{3}$
}

${ }_{1}^{1}$ Senior Resident, Department of Pulmonary Medicine, Sri Manakula Vinayagar Medical College and Hospital, Puducherry.

${ }^{2}$ Post Graduate, Department of Pulmonary Medicine, Sri Manakula Vinayagar Medical College and Hospital, Puducherry.

${ }_{3}^{3}$ Assistant Professor, Department of Pulmonary Medicine, Sri Manakula Vinayagar Medical College and Hospital, Puducherry.

\begin{abstract}
Mixed Connective Tissue Disorder (MCTD) is an overlap syndrome with features predominantly of Systemic Lupus Erythematosus (SLE), polymyositis-dermatomyositis and scleroderma. Pleuropulmonary complications are common among this group of patients. Interstitial lung diseases are most common pulmonary complications.
\end{abstract}

\section{KEYWORDS}

Mixed Connective Tissue Disorder, Interstitial Lung Disease, Pulmonary Fibrosis, Anti-U1 RNP.

HOW TO CITE THIS ARTICLE: Thomas BK, Radhakrishnan P, Yuvarajan S. A case of mixed connective tissue disorder with interstitial lung disease: case report. J. Evolution Med. Dent. Sci. 2016;5(33):1860-1862, DOI: 10.14260/jemds/2016/438

\section{INTRODUCTION}

Mixed connective tissue disorder is a disease characterized by elevated titres of specific antinuclear antibody against U1 ribonucleoprotein (Anti-U1 RNP). Most common components of MCTD are SLE, polymyositis-dermatomyositis and scleroderma. But other features like Raynaud's phenomenon, swelling of both hands, oesophageal dysmotility, arthritis and myositis may be present. Pleuropulmonary complication are most common in MCTD. Interstitial lung disease, pulmonary vascular disease, aspiration pneumonia and pleurisy are common among which Interstitial Lung Disease is most common with an usual Interstitial Pneumonia (UIP) or NonSpecific Interstitial Pneumonia Pattern (NSIP).

\section{CASE REPORT}

- 70 yrs. old retired school teacher presented to our hospital with chief complaints of cough for the past one and a half years, breathlessness (MMRC grade 3) for the past 1 year which is gradual in onset, progressive in nature. History of photosensitivity and swelling of both hands present. Past history of tuberculous lymphadenitis for which he has completed treatment (Six months).

- On examination vitals were stable, swelling of hands present, upper respiratory tract was normal. On auscultation breath sounds reduced in intensity bilaterally with late inspiratory fine crepitations heard over bilateral infraaxillary and infrascapular areas. Other systems were normal.

- Investigations done: complete blood count showed haemoglobin of $9.6 \mathrm{~g} / \mathrm{dL}$, otherwise normal. Blood sugar, renal and liver profiles were normal. Rheumatoid and Creactive protein were negative.

- Chest X-ray was done showed bilateral lower zone reticular opacities.

Financial or Other, Competing Interest: None.

Submission 15-02-2016, Peer Review 01-04-2016,

Acceptance 06-04-2016, Published 25-04-2016.

Corresponding Author:

Praveen Radhakrishnan,

No. 35, Fourth Cross,

Annanagar-605005,

Pondicherry.

E-mail:dr.praveen.rr@gmail.com

DOI: $10.14260 /$ jemds/2016/438
- Spirometry showed restrictive pattern with no significant FEV 1 reversibility with bronchodilators.

- Bronchoscopy was done - within normal limits. BAL AFB, GRAM STAIN=NO ORGANISMS.

- High Resolution Computed Tomography [HRCT] was suggestive of Usual Interstitial Pneumonia (UIP) pattern [Fig. 2, 3].

- $\quad$ Extractable nuclear antigen profile.

$\begin{array}{lll}\mathrm{n} \mathrm{RNP} / \mathrm{Sm} & = & \text { POSITIVE }+++ \\ \mathrm{Sm} & = & \text { POSITIVE }+ \\ \mathrm{SS}-\mathrm{A} & = & \text { NEGATIVE } \\ \text { Ro }-52 & = & \text { POSITIVE }+ \\ \text { Nucleosomes } & = & \text { POSITIVE }+ \\ \text { Ribosomal -P Protein } & = & \text { POSITIVE }+++ \\ \text { AMA -M2 } & = & \text { POSITIVE }++\end{array}$

2D echo: no evidence of pulmonary hypertension.

Patient was diagnosed as MCTD with interstitial lung disease. Started on oral prednisolone and azathioprine and gradually steroid was tapered. Other supportive measures were given. Patient improved symptomatically and was advised followup.



Fig. 1: Chest X-ray (PA View) showing Reticular Shadows in the Bilateral Lower Zones 




Fig. 2

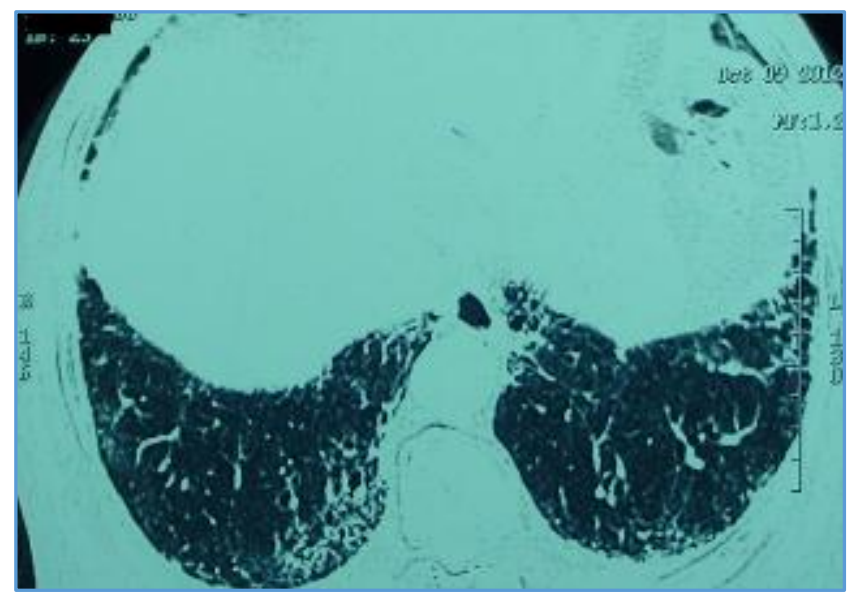

Fig. 2 and 3: HRCT Thorax: Bilateral Basal Subpleural Reticular Shadows with Honeycombing
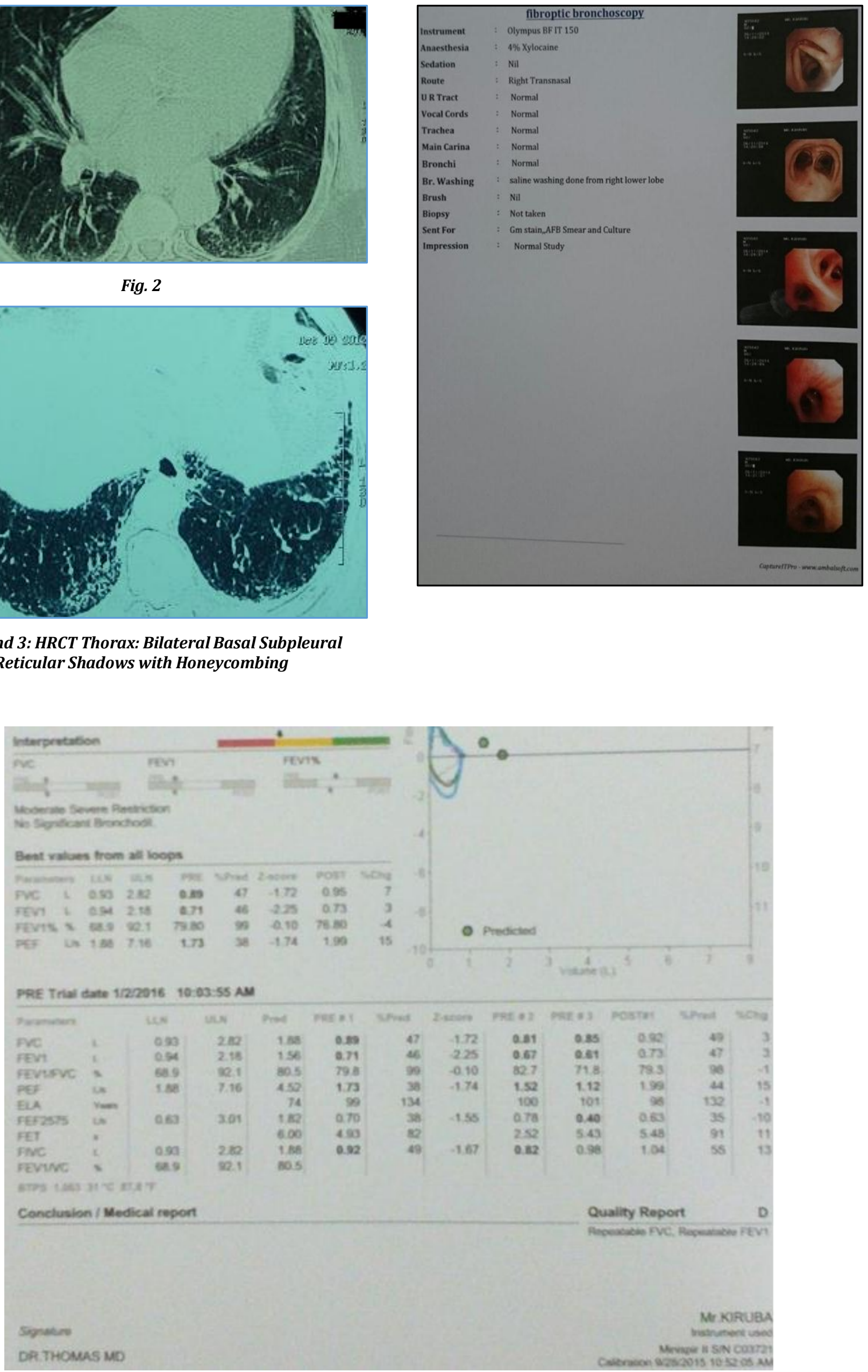




\section{DISCUSSION}

- Mixed connective tissue disease is relatively rare and the vast majority of people with the disease ( 80 percent) are women. The diagnosis of MCTD could be established using the criteria described by Alarcon-Segovia and Villarreal.[1] The crux of the MCTD diagnosis is the presence of high titres of antibodies to U1-RNP. With serology superseding the clinical symptoms in the diagnosis, there is a risk of fitting the clinical symptoms to the antibody signs.

- ILD is the most common pulmonary manifestation of MCTD. The reported frequency of ILD in MCTD is between 21 and 50\%.[2,3] Other pleuropulmonary involvement includes pulmonary hypertension and pleurisy. Cardiac involvement is rare causing pericarditis. ${ }^{[4]}$
- In a study by Gunnarasson et al of 126 patients with MCTD, $52 \%$ of them had HRCT features consistent with interstitial lung disease.[5]

- It is important to look for pulmonary involvement in case of MCTD.

- High resolution CT should be done routinely for these patients. Early detection and timely immunosuppression could benefit a subset of these patients.[6,7]

- There is no specific treatment for MCTD. Drugs to suppress the inflammation including steroids, nonsteroidal anti-inflammatory drugs and immunesuppressive agents are used.

\section{REFERENCES}

1. Bodolay E, Szekanecz Z, Devenyi K, et al. Evaluation of interstitial lung disease in mixed connective tissue disease (MCTD). Oxford journal of rheumatology 2005;44(5):656-61.

2. Prakash UB. Respiratory complications in mixed connective tissue disease. Clin Chest Med 1998;19(4):733-46.

3. Sharp GC, Singsen BH. Mixed connective tissue disease. In: mccarty DJ, Arthritis and allied conditions: a textbook of rheumatology, Philadelphia: Lea and Febiger, 1989;11 th edn:1080-91.

4. Kumar MS, Smith M, Pischel KD. Case report and review of cardiac tamponade in mixed connective tissue disease. Arthritis \& Rheumatism 2006;55(5):826-30.

5. Gunnarsson R, Aalokken TM, Molberg, et al. Prevalence and severity of interstitial lung disease in mixed connective tissue disease: a nationwide, cross-sectional study. Ann Rheum Dis 2012;71(12):1966-72.

6. Remy-Jardin M, Remy J, Deffontaines C, et al. Assessment of diffuse infiltrative lung disease: comparison of conventional CT and high resolution CT. Radiology 1991;181(1):157-62.

7. Harpreet K Lota. Interstitial lung disease in patients with mixed connective tissue disease. Thorax 2013;68:11786. 